\title{
Allelopathic Potential of Green Manure Cover Crops on Germination and Early Seedling Development of Goose Grass [Eleusine indica (L.) Gaertn] and Blackjack (Bidens pilosa L.)
}

\author{
Joyful Tatenda Rugare $\mathbb{D}^{1,2}$ Petrus Jacobus Pieterse $\mathbb{D}^{2},{ }^{2}$ and Stanford Mabasa $\mathbb{D}^{2}$ \\ ${ }^{1}$ Department of Agronomy, Stellenbosch University, Private Bag X1, Matieland 7602, South Africa \\ ${ }^{2}$ Department of Plant Production Sciences and Technologies, University of Zimbabwe, P.O. Box MP 167, Mount Pleasant, \\ Harare, Zimbabwe
}

Correspondence should be addressed to Joyful Tatenda Rugare; rugarejoy@yahoo.co.uk

Received 22 June 2021; Revised 24 September 2021; Accepted 13 October 2021; Published 1 November 2021

Academic Editor: Yong In Kuk

Copyright ( $(2021$ Joyful Tatenda Rugare et al. This is an open access article distributed under the Creative Commons Attribution License, which permits unrestricted use, distribution, and reproduction in any medium, provided the original work is properly cited.

\begin{abstract}
Green manure cover crops (GMCCs), which are recommended for improving soil fertility, also have the potential of reducing weed populations in cropping systems through allelopathy. The objective of this study was to evaluate the effect of eight GMCCs on the germination and seedling development of two weeds of divergent morphology, namely, goose grass [Eleusine indica (L.) Gaertn] and blackjack (Bidens pilosa L.). Aqueous leaf, stem, and root extracts of hyacinth bean (Lablab purpureus L), red sunnhemp [Crotalaria ochroleuca (G.) Don], showy rattlebox (Crotalaria grahamiana Wight \& Arn.), common bean (Phaseolus vulgaris L.), common rattlepod (Crotalaria spectabilis Roth.), radish (Raphanus sativus L.), tephrosia (Tephrosia vogelii L.), and black sunnhemp (Crotalaria juncea L.) at $0,1.25,2.5,3.75$, and $5 \% \mathrm{wv}^{-1}$ were applied to weed seeds in Petri dishes to determine their effect on germination, radicle and plumule growth, and germination vigor index. The experimental design was 3 (tissue types) * 5(concentrations) treatment combinations replicated four times in a completely randomized design. In the pot study, 25 seeds of either goose grass or blackjack were planted separately in approximately $400 \mathrm{~g}$ of soil mixed with cover crop tissue powder at $1 \%$ concentration per pot. The experimental design was cover crop residues + control replicated four times in randomized complete blocks. There was a significant $(p<0.05)$ extract $*$ concentration interaction on all germination parameters across all GMCCs. The different cover crop aqueous extracts differentially reduced all germination parameters of both weeds in the order leaf $>$ stem $>$ root extract except for radish root extracts being most inhibitory to all germination parameters of goose grass. The leaf, stem, and root soil-incorporated residues of GMCCs significantly $(p<0.05)$ affected seedling emergence, dry weight, and vigor indices of both weeds. Based on the results of this study, it was concluded that the different GMCC tissues contain allelochemicals that inhibit the emergence of both monocotyledonous and dicotyledonous weeds.
\end{abstract}

\section{Introduction}

The widespread and improper use of synthetic herbicides leads to environmental damage and a surge in the development of herbicide-resistant weed biotypes [1]. This has created the need for alternative sustainable weed control methods. Crop rotations with GMCCs, mainly practiced in conservation agriculture (CA) and organic farming, are arguably the most efficacious, environmentally friendly, and economically feasible alternative or complement to herbicides [2]. Cover crops play an important role in integrated weed management (IWM) either as smother crops, mulches, or allelopathic crops [3].

Most of the cover crops that are being promoted in the smallholder sector of Zimbabwe are fast growing and produce a lot of biomass, resulting in rapid canopy closure, which smothers weeds when they are used as live mulches [4]. Alternatively, their dead residues may be used as surface mulches or be incorporated into the soil. Weed suppression when cover crop residues are incorporated into the soil may occur via altered nutrient dynamics depending on several other factors including type of tillage used, carbon to 
nitrogen ratio $(\mathrm{C}: \mathrm{N})$ of the decomposing cover crop material, soil type, and the environment [5]. In addition, cover crops can suppress weeds by competing for resources [6], disruption of life cycles of crop bound and crop associated weeds [7], through resource and light competition [8, 9], creation of soil conditions that promote seed decay and predation [10], and prevention of weed seed set and dispersal [5]. Furthermore, some cover crops such as stooling rye (Secale cereal L.), barley (Hordeum vulgare L.), and black sunnhemp (Crotalaria juncea L.) have demonstrated allelopathic activity [11-13]. Ferreira and Reinhardt [14] reported the possibility of using cover crops to manage herbicide-resistant weeds.

Allelopathy, a phenomenon occurring in natural or agricultural communities of plants is defined as the inhibitory or stimulatory effects of one plant species on another through the release of chemicals called allelochemicals [15]. Allelochemicals are released by live plants directly into the environment as volatiles, leachates, and/or root exudates [16]. The allelochemicals are also released when the residues of the plants decompose [17]. According to Ayeni [18], allelopathy can be exploited to achieve reduced application of synthetic herbicides, since most allelochemicals do not have residual effects and can, therefore, be exploited for early season weed control in arable fields without affecting successive crops in crop rotations. Barberi and Lo Cascio [19] reported that the maize-cover crop rotations reduced weed density under field conditions demonstrating the possibility of exploiting allelopathic cover crops for effective weed control in IWM.

The fact that allelopathic effects from decomposing cover crop residues were reported to be more pronounced on small seeds and early emerging species compared to large-seeded crops, which offers an opportunity for exploiting them for selective weed control in arable crop production [20]. Aqueous extracts of velvet bean (Mucuna pruriens L) and Jack bean (Canavalia ensiformis L.) reduced weed germination and early seedling development $[21,22]$.

Most of the cover crops being proposed for adoption in smallholder CA are legumes with a low carbon to nitrogen $(\mathrm{C}: \mathrm{N})$ ratio resulting in a faster decomposition than cereal residues that have higher $\mathrm{C}: \mathrm{N}$ ratios [23]. As such, when allelopathic materials of leguminous cover crops are applied in the field, a considerable amount of nutrients are added, which may cause stimulation of weed growth due to mineralisation $[23,24]$ and hormesis. The need for finding allelopathic cover crops whose phytotoxicity outweighs their weed growth stimulation activity is, therefore, indispensable [25]. This work aimed at the assessment of the allelopathic potential of leaf, stem, and root aqueous extracts and incorporated biomass of eight cover crops that are being promoted for the adoption in smallholder CA in Zimbabwe. The hypothesis tested in the present study was that aqueous extracts and soil-incorporated cover crop biomass suppress blackjack (Bidens pilosa L.) and goose grass [Eleusine indica (L.) Gaertn] germination, emergence, and early seedling growth.

\section{Materials and Methods}

2.1. Experimental Site. The study was carried out at the University of Zimbabwe (UZ) situated at $17.78^{\circ} \mathrm{S} ; 31.05^{\circ} \mathrm{E}$ with an altitude of $1523 \mathrm{~m}$ above sea level. Laboratory bioassays were carried out in Petri dishes in the Weed Science laboratory, and pot experiments were carried out in a greenhouse at the Department of Plant Production Sciences and Technologies between January 2015 and June 2016. Average day and night temperatures in the glasshouse were $28.1^{\circ} \mathrm{C}$ and $15.2^{\circ} \mathrm{C}$. No artificial light was used in the glasshouse.

2.2. Biomass Preparation. The GMCCs used in the study were grown under irrigation in a field at UZ's Department of Plant Production Sciences and Technologies in September 2014. The GMCCs were grown in soils with $18 \%$ clay, $16 \%$ silt, and $66 \%$ sand with a $\mathrm{pH}\left(\mathrm{CaCl}_{2}\right)$ of 5.2 . Exchangeable cations in milliequivalents percent (me \%) of soil were 7.61 , 4.17, and 0.32 for calcium, magnesium, and potassium, respectively. Green manure cover crops were grown in the field at the University of Zimbabwe as described in Rugare et al. [26]. The preparation of dry biomass powder was done following the method described by Rugare et al. [21] without any amendments.

2.3. Aqueous Extract Preparation. Fifty grams of GMCC powder were soaked in $1000 \mathrm{ml}$ distilled water to produce a $5 \% \mathrm{wv}^{-1}$ solution on a dry weight basis. The solution was then stirred for 24 hours at room temperature $\left(25^{\circ} \mathrm{C}\right)$ on an orbital shaker at $100 \mathrm{rpm}$. The extracts were then strained through four layers of cheese cloth before being centrifuged at $4000 \mathrm{rpm}$ for 15 minutes. The clear solution was pipetted to separate it from the supernatant. This stock solution was then stored in parafilm sealed bottles at $4^{\circ} \mathrm{C}$ for 24 hours before being used. The stock solution was then diluted with distilled water to produce $1.25 \%, 2.5 \%$, and $3.75 \%$ plant extracts prior to use. Conductivity of the $5 \% \mathrm{wv}^{-1}$ aqueous extract concentrations of the ten GMCCs was measured using a conductivity meter (Model SX713 version 2.02013 7-30), and the values obtained were used to calculate the osmotic potential using the following formula [27]:

Osmotic potential (in $\mathrm{MPa})=$ conductivity (in $\mathrm{mS}$ )

Osmotic potential values for the different stock solutions ( $5 \% \mathrm{wv}^{-1}$ concentrations) of the different GMCC tissue aqueous extract treatments ranging from -0.26 to -0.09 .

In order to ascertain whether the inhibitory activity exhibited by different extract concentrations of the cover crop tissues was not due to differences in the osmotic pressure of the solutions, germination bioassays were conducted using polyethylene glycol (PEG) 6000 solutions at $0.00,0.05,0.10,0.15,0.20,0.25$, and $0.30 \mathrm{MPa}$ (i.e., the range of osmotic potentials of the $5 \% \mathrm{wv}^{-1}$ of the cover crop tissues). 
2.4. Effect of Cover Crop Aqueous Extracts on Weed Seed Germination and Early Seedling Growth. The weed bioassays were carried out in the Weed Science laboratory between January and March 2015. The weed laboratory bioassays for individual GMCCs were laid out as $3 * 5$ factorial experiments with two factors in a completely randomized design (CRD) with four replications. The factors were extract tissue type at three levels (leaf, stem, and root) and extract concentration at five levels $(0,1.25,2.50,3.75$, and $5 \%)$. In all the laboratory experiments, distilled water was used as the control. Each weed species was considered a separate experiment, and the experiments were repeated once. Twentyfive seeds of the respective weeds were counted, sterilised in $1 \%$ sodium hypochlorite for 10 minutes, rinsed four times with distilled water, and placed in $90 \mathrm{~mm}$ diameter Petri dishes lined with Whatman No. 2 filter paper. The seeds in the Petri dishes were treated with $10 \mathrm{ml}$ of the respective extract concentration, sealed with parafilm, and placed randomly on a table in the laboratory at room temperature (approximately $25^{\circ} \mathrm{C}$ day temperature). Data on germination, plumule, and radicle length were collected from five randomly selected plants on day 10 and day 14 in blackjack and goose grass, respectively. Germination was considered to have occurred when the radicle was $2 \mathrm{~mm}$ long. Germination percentage $(G \%)$ and germination vigor indices (VI) were calculated using the formulae given below

$$
G \%=\left(\frac{a}{b}\right) * 100
$$

where $a$ is the number of germinated seeds and $b$ is the total number of seeds in each Petri dish.

$\mathrm{VI}=$ Germination $\quad(\%) *($ radicle + plumule length $)$ [28].

2.5. Greenhouse Experiment. The glasshouse study was carried out using the method described by Rugare et al. [21].
Each pot experiment was laid out as a completely randomized design (CRD). The effect of the different cover crop tissues on the emergence and seedling growth of goose grass and blackjack were compared separately (i.e., leaves of the different cover crops and the stems and roots were evaluated separately). No cover crop residues were put in the control pots. The pot experiments were replicated four times, and only goose grass experiments were repeated once. The soil used in the goose grass bioassays was granite-derived sands from Domboshava $\left(17^{\circ} 37^{\prime} \mathrm{S}, 31^{\circ} 10^{\prime} \mathrm{E}\right.$ and 1560 metres above sea level), whereas UZ red soils were used in the blackjack bioassay in order to mimic edaphic factors under which the two weeds exert their dominance [22]. The chemical and physical properties of the soils used are shown in Table 1.

Pots measuring $90 \mathrm{~mm}$ bottom diameter, $105 \mathrm{~mm}$ top diameter, and $65 \mathrm{~mm}$ height were filled with $400 \mathrm{~g}$ of soil in which one Gram of compound D $\left(7 \% \mathrm{~N}, 14 \% \mathrm{P}_{2} \mathrm{O}_{5}, 7 \%\right.$ $\mathrm{K}_{2} \mathrm{O}$ ) was added. The respective cover crop tissue powder was thoroughly mixed with soil at a concentration of $1 \%$ [cover crop biomass concentration adopted from CaamalMaldonado et al. [29] and Fujii [30]] aiming to provide a concentration of the cover crop residues similar to what would be obtained by the cover crops in nutrient depleted soils under dry land conditions. Thereafter, 25 seeds of the respective weed species were counted and placed on the soil surface in the pots after which they were covered with a thin layer of soil. A uniform amount of tap water of $150 \mathrm{ml}$ was applied to the pots daily using a perforated cup. The number of emerged goosegrass and blackjack seedlings in the pots was recorded daily until no further emergence was noted. The final emergence percentage was calculated using the following formula:

$$
\text { emergence percentage }=\frac{\text { number of emerged seeds }}{\text { total number of seeds in each pot }} \times 100 \text {. }
$$

On day 21 after planting of the weed seeds, the seedlings were harvested and washed gently with tap water to remove any soil from the roots. The uprooted weeds were oven-dried for 72 hours at $70^{\circ} \mathrm{C}$ to obtain the dry weight of the weeds. The seedling vigor index (SVII) was calculated using the formula adopted from Abdul-Baki and Anderson [28] as follows:

SVII $=$ seedling emergence $\% \times$ seedling dry weight $(\mathrm{g})$.

The inhibition of different cover crop plant parts was evaluated using the method of Hong et al. [24], where inhibition magnitudes were ranked based on the mean inhibition of leaf, stem, and root soil incorporated biomass in descending order. The average inhibition percentages were then grouped into three categories where more than $80 \%$, $50 \%$, and $20 \%$ were classified as the first, second, and third strongest inhibitory degree, respectively. The inhibition percentage was calculated as follows:

$$
\text { inhibition percentage }=\left[1-\frac{\text { treatment }}{\text { control }}\right] * 100 \text {. }
$$

2.6. Data Analysis. The data were tested for normality using the Shapiro-Wilk test and subjected to analysis of variance (ANOVA) using Genstat $18^{\text {th }}$ edition. The seedling vigor index (SVII) data did not meet the assumptions of ANOVA and were $\sqrt{ }(x+0.5)$ transformed before being analysed 
TABLe 1: Physical and chemical properties of soil that was used in the study.

\begin{tabular}{|c|c|c|c|c|c|c|c|c|c|c|c|c|}
\hline $\begin{array}{l}\text { Soil } \\
\text { properties }\end{array}$ & \% Clay & $\%$ Silt & \% Sand & Ca me \% & Mg me $\%$ & K me \% & Na me \% & CEC me \% & $\% \mathrm{H}_{2} \mathrm{O}$ & $\begin{array}{c}\% \\
\text { Organic } \\
\text { carbon }\end{array}$ & $\begin{array}{c}\mathrm{pH} \\
\left(\mathrm{CaCl}_{2}\right)\end{array}$ & $\begin{array}{c}\% \\
\text { Organic } \\
\text { matter }\end{array}$ \\
\hline \multirow{2}{*}{$\begin{array}{l}\text { UZ red soil } \\
\text { Domboshava } \\
\text { sand soil }\end{array}$} & 18 & 16 & 66 & 7.61 & 4.17 & 0.32 & 0.22 & 12.32 & 2.98 & 1.66 & 5.20 & 3.32 \\
\hline & 7 & 5 & 88 & 4.6 & 0.2 & 0.23 & 0.46 & 2.81 & 1.76 & 0.41 & 0.05 & 0.61 \\
\hline
\end{tabular}

me $(\%)=$ milliequivalents percent.

using Genstat version 18. Significantly different means were separated using Fischer's protected least significance difference (LSD) at 5\% significance level.

\section{Results}

3.1. Germination and Early Seedling Growth of Blackjack and Goosegrass in PEG 6000 Solutions. The seedling vigor index of goose grass seeds was significantly $(p<0.05)$ affected by the different PEG solutions (Table 2). On the other hand, there were no significant differences in the seedling vigor index of blackjack in PEG 6000 solutions of different osmotic potentials (Table 2 ).

\subsection{Effect of GMCC Aqueous Extracts on Goose Grass and} Blackjack Germination Parameters. The interaction of extract tissue and concentration was significant $(p<0.05)$ on the germination percentage of goose grass and blackjack across all the GMCCs (Table 3). Leaf extracts reduced the germination of both weeds significantly better than the stem and root extracts. Similarly, the interaction between extract tissue and concentration was significant $(p<0.05)$ on radicle and plumule length of goosegrass and blackjack across all GMCCs (Tables 4 and 5, respectively). GMCC aqueous extracts exhibited phytotoxic activity on radicle growth in the order leaf $>$ root $>$ stem. Consequently, leaf extracts significantly $(p<0.5)$ reduced the germination vigor index better than the other tissue extracts across all the GMCCs except radish, whose root extracts showed greater phytotoxic activity than the other extract tissues (Table 6).

\subsection{Effect of Cover Crop Soil-Incorporated Residues on} Emergence, Dry Weight, and Seedling Vigor Index of Blackjack. The emergence of blackjack was significantly $(p<0.05)$ affected by different cover crop leaf, stem, and root soil-incorporated residues (Table 7). Leaf, stem, and root soilincorporated biomass inhibited blackjack seedling emergence by $42-96 \%, 49-94 \%$, and 46-93\%, respectively. Generally, the leaf tissues were more inhibitory than the stem and root tissues. Overall, tephrosia and hyacinth bean residues inhibited blackjack emergence significantly $(p<0.05)$ better than the other cover crops with a percentage mean inhibition of above $80 \%$. Leaf, stem, and root soilincorporated residues of all cover crops significantly $(p<0.05)$ suppressed the dry weight of blackjack (Table 7). Results showed that among the eight cover crop species, common bean, hyacinth bean, and tephrosia exhibited the greatest average suppression on dry weight of blackjack with a mean inhibition above $80 \%$ over the control. A showy
TABLE 2: Effect of different osmotic potentials of polyethylene glycol (PEG) solutions on the seedling vigor index of blackjack and goose grass.

\begin{tabular}{lcc}
\hline PEG solution osmotic potential (MPa) & Goose grass & Blackjack \\
\hline 0.00 & $1634.2^{\mathrm{b}}$ & 5807.2 \\
0.05 & $2479.7^{\mathrm{a}}$ & 6088.3 \\
0.10 & $2433.3^{\mathrm{a}}$ & 5624.0 \\
0.15 & $1772.6^{\mathrm{b}}$ & 6046.6 \\
0.20 & $1542.9^{\mathrm{b}}$ & 5926.6 \\
0.25 & $2471.0^{\mathrm{a}}$ & 5201.8 \\
0.30 & $2088.8^{\mathrm{ab}}$ & 6005.1 \\
\hline p value & 0.013 & 0.202 \\
LSD & 652.63 & $\mathrm{NS}$ \\
\hline
\end{tabular}

Means followed by different letters in the same column are significantly different at $p<0.05$.

rattlebox showed the least mean inhibition of $46 \%$. The seedling vigor index of the blackjack was significantly $(p<0.05)$ reduced by different tissue residues of the cover crops (Table 7). Percentage inhibition ranged from 82-99\%, $76-100 \%$, and $73-97 \%$ over control where leaf, stem, and root residues were used, respectively. Overall, all the cover crops were ranked to be in the first level of allelopathic potential with mean inhibition above $80 \%$.

3.4. Effect of Cover Crop Soil-Incorporated Biomass on Emergence, Dry Weight, and Seedling Vigor Index of Goose Grass. Leaf biomass of all the cover crops except showy rattlebox exhibited significant $(p<0.05)$ phytotoxic activity on the emergence of goose grass with inhibition percentages that ranged from $24-56 \%$ (Table 8 ). Most of the cover crops caused a weak inhibition of goose grass emergence except jack bean, hyacinth bean, red sunnhemp, and common rattlepod that reduced emergence by more than $50 \%$ over the control. Similarly, stem residues apart from the showy rattlebox exhibited significant $(p<0.05)$ allelopathic activity on the emergence of goose grass with the highest percentage reduction of $70 \%$ being observed where black sunnhemp stem residues were mixed with the soil. Except for showy rattlebox and common bean, soil incorporated root residues of cover crops significantly $(p<0.05)$ reduced the emergence of goose grass. Radish and hyacinth bean caused the highest inhibition percentage over the control compared to the other cover crops. Results in Table 8 show that the effect of the cover crop leaf residue type on the dry weight pot $^{-1}$ of goose grass was significant $(p<0.05)$. The soil-incorporated stem biomass of the cover crops significantly $(p<0.05)$ reduced goose grass dry weight by $57-97 \%$, except showy rattlebox residues that stimulated weed growth by $12 \%$ above the 
TABLE 3: Effect of aqueous extracts of eight green manure cover crops on germination percentage of goose grass and blackjack.

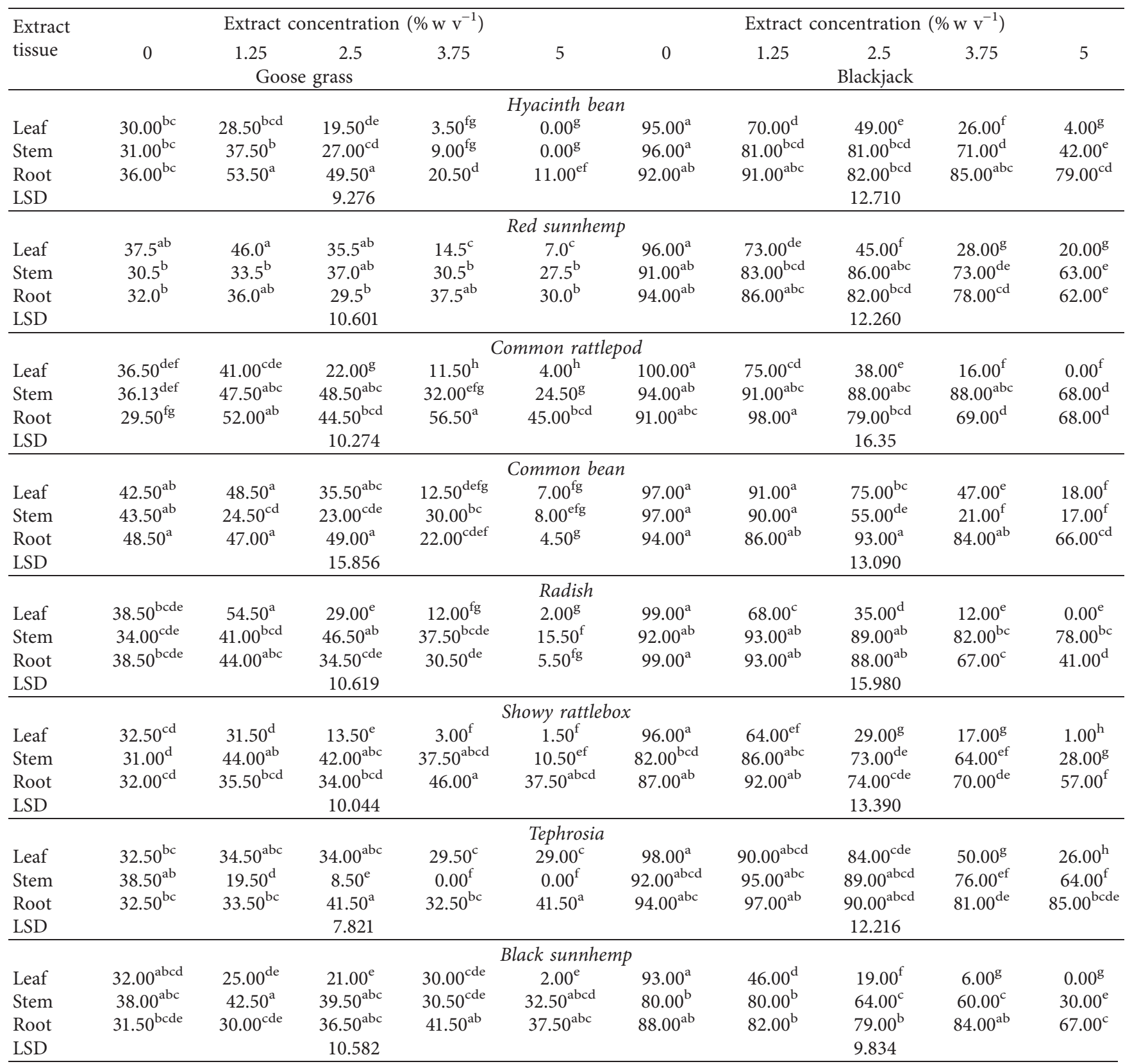

Means followed by the same letter for each GMCC are not significantly different at $p<0.05$.

control. Red sunnhemp, common bean, common rattlepod, and black sunnhemp showed strong allelopathic potential with mean inhibition percentages that were above $80 \%$. Two cover crops (red sunnhemp and common rattlepod) significantly $(p<0.05)$ suppressed seedling vigor of goose grass by more than $80 \%$ over the control.

\section{Discussion}

Results obtained demonstrated that all the GMCC extracts used in this study inhibited the germination and early seedling growth of goosegrass and blackjack. The degree of inhibition varied greatly amongst the different cover crops and tissues within each cover crop with leaf extracts showing the greatest phytotoxic activity followed by the stems, except radish root extracts that were more efficient on goosegrass than the other tissue extracts. The inhibition of germination of both weeds, especially by leaf extracts of all the cover crops except radish on goosegrass suggests the presence of allelochemicals in these GMCCs. The reduced seedling growth caused by the cover crop extracts could also imply reduced early seedling growth, which would give the crops a head start and competitive advantage over the weeds resulting in reduced crop-weed competition during the early stages of crop development when crop seedlings would be sensitive to weed pressure [21]. The seedling vigor index gives the overall effect of the treatments on seedling germination and growth [31]. In this study, leaf extracts of all the GMCCs and root 
TABLE 4: Effect of aqueous extracts of eight green manure cover crops on the radicle length of goose grass and blackjack.

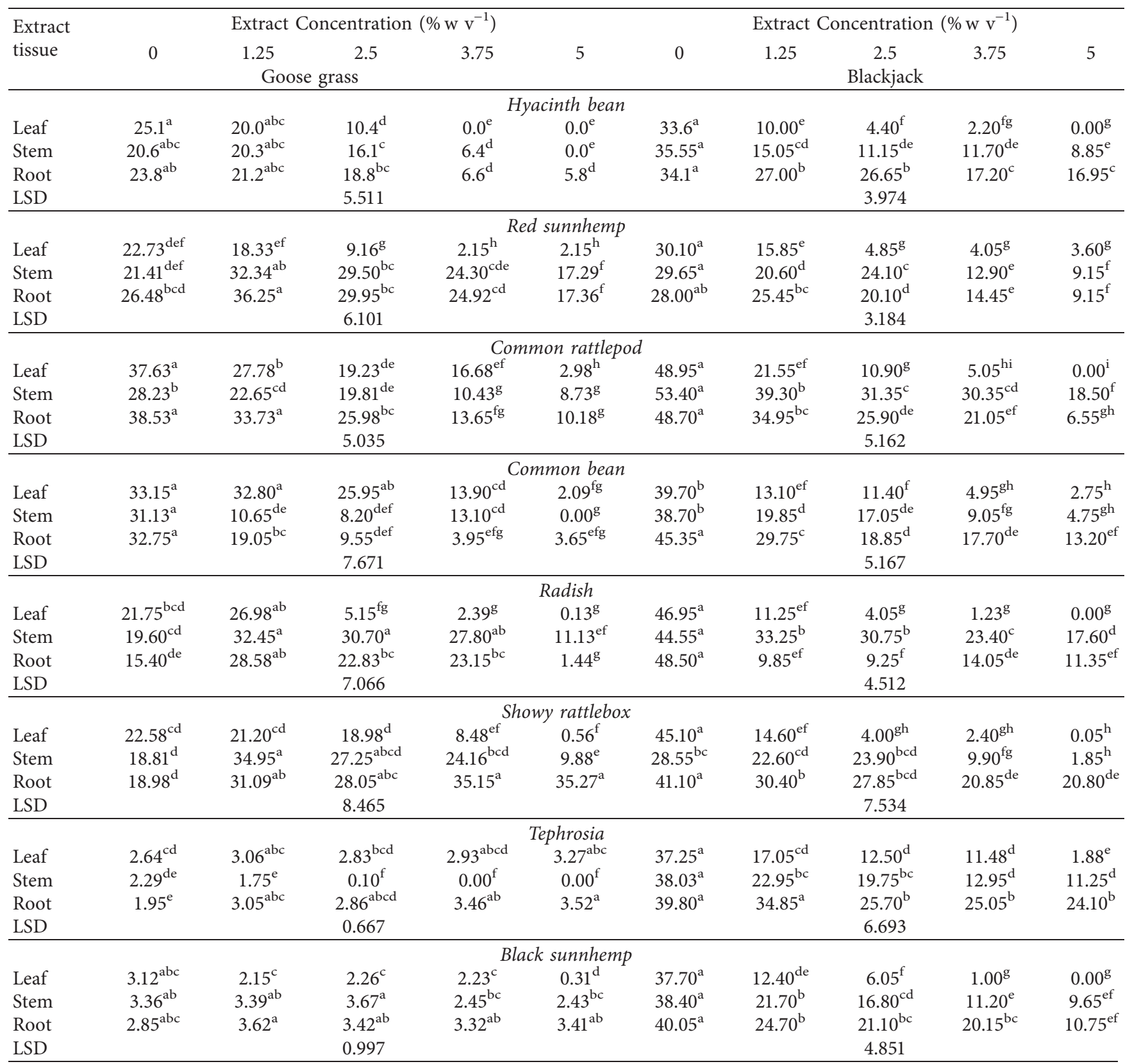

Means followed by the same letter for each GMCC are not significantly different at $p<0.05$.

extracts of radish reduced the seedling vigor index, demonstrating their effectiveness in suppressing germination and early seedling growth of monocotyledonous and dicotyledonous weeds.

Generally, the inhibitory effects of aqueous solutions in Petri dish experiments could be attributed to factors such as allelopathy and variations in osmotic potential [27, 32]. In this study, the osmotic potentials of the different cover crop aqueous extracts that were equivalent to those of PEG solutions used in the study did not affect seed germination and seedling development, and as such it is highly unlikely that the osmotic potentials observed could have caused any inhibitory effect on germination and early seedling growth of plants [33]. When osmotic potential values show little effect amongst treatments, they probably have no effect on the germination traits evaluated [27]. Therefore, the inhibitory activity of extracts observed in this present study could be attributed to the presence of phytotoxic allelochemicals in aqueous extracts of the cover crops [34].

The inhibition of germination and early seedling development of both goosegrass and blackjack that was observed in this study indicated that the green manure cover crops possess allelochemicals with strong phytotoxic activity. The inhibition that was observed was concentration dependent. The findings corroborate with the earlier findings of Runzika et al. [35] who reported weed germination 
TABLE 5: Effect of aqueous extracts of eight green manure cover crops on the plumule length of goose grass and blackjack.

\begin{tabular}{|c|c|c|c|c|c|c|c|c|c|c|}
\hline \multirow{3}{*}{$\begin{array}{l}\text { Extract } \\
\text { tissue }\end{array}$} & \multicolumn{5}{|c|}{ Extract concentration $\left(\% \mathrm{w} \mathrm{v}^{-1}\right)$} & \multicolumn{5}{|c|}{ Extract concentration $\left(\% \mathrm{w} \mathrm{v}^{-1}\right)$} \\
\hline & 0 & 1.25 & 2.5 & 3.75 & 5 & 0 & 1.25 & 2.5 & 3.75 & 5 \\
\hline & \multicolumn{5}{|c|}{ Goose grass } & \multicolumn{5}{|c|}{ Blackjack } \\
\hline \multicolumn{11}{|c|}{ Hyacinth bean } \\
\hline Leaf & $17.8^{\mathrm{a}}$ & $17.2^{\mathrm{a}}$ & $11.1^{\mathrm{cd}}$ & $1.8^{\mathrm{e}}$ & $0.0^{\mathrm{e}}$ & $22.85^{\mathrm{bc}}$ & $20.75^{\mathrm{bc}}$ & $14.05^{\mathrm{de}}$ & $5.30^{\mathrm{fg}}$ & $0.55^{\mathrm{g}}$ \\
\hline Stem & $18.1^{\mathrm{a}}$ & $16.3^{\mathrm{ab}}$ & $13.8^{\mathrm{bc}}$ & $9.9^{\mathrm{d}}$ & $0.0^{\mathrm{e}}$ & $23.50^{\mathrm{b}}$ & $22.45^{\mathrm{bc}}$ & $16.75^{\mathrm{cd}}$ & $13.55^{\mathrm{de}}$ & $9.40^{\mathrm{ef}}$ \\
\hline Root & $17.8^{\mathrm{a}}$ & $15.7^{\mathrm{ab}}$ & $18.1^{\mathrm{a}}$ & $13.4^{\mathrm{bc}}$ & $10.5^{\mathrm{cd}}$ & $22.95^{\mathrm{bc}}$ & $30.90^{\mathrm{a}}$ & $30.15^{\mathrm{a}}$ & $19.05^{\mathrm{bcd}}$ & $21.10^{\mathrm{bc}}$ \\
\hline LSD & & & 3.305 & & & & & 6.287 & & \\
\hline \multicolumn{11}{|c|}{ Red sunnhemp } \\
\hline Leaf & $16.23^{\mathrm{b}}$ & $19.30^{\mathrm{ab}}$ & $16.90^{\mathrm{ab}}$ & $10.28^{\mathrm{c}}$ & $3.31^{\mathrm{d}}$ & $28.20^{\mathrm{bc}}$ & $30.25^{\mathrm{abc}}$ & $13.55^{\mathrm{f}}$ & $1.45^{\mathrm{g}}$ & $4.50^{\mathrm{g}}$ \\
\hline Stem & $16.25^{\mathrm{b}}$ & $18.24^{\mathrm{ab}}$ & $18.75^{\mathrm{ab}}$ & $17.88^{\mathrm{ab}}$ & $16.48^{\mathrm{b}}$ & $28.60^{\mathrm{bc}}$ & $31.90^{\mathrm{ab}}$ & $36.00^{\mathrm{a}}$ & $21.10^{\text {de }}$ & $15.05^{\mathrm{ef}}$ \\
\hline Root & $16.60^{\mathrm{ab}}$ & $18.73^{\mathrm{ab}}$ & $15.98^{\mathrm{b}}$ & $20.28^{\mathrm{a}}$ & $16.75^{\mathrm{ab}}$ & $30.05^{\mathrm{abc}}$ & $33.20^{\mathrm{ab}}$ & $28.40^{\mathrm{bc}}$ & $24.40^{\mathrm{cd}}$ & $19.60^{\mathrm{def}}$ \\
\hline LSD & & & 3.746 & & & & & 6.321 & & \\
\hline \multicolumn{11}{|c|}{ Common rattlepod } \\
\hline Leaf & $18.20^{\mathrm{b}}$ & $17.78^{\mathrm{bc}}$ & $16.83^{\mathrm{bc}}$ & $13.78^{\mathrm{c}}$ & $4.58^{\mathrm{d}}$ & $21.35^{\mathrm{b}}$ & $28.60^{\mathrm{a}}$ & $15.30^{\mathrm{cd}}$ & $6.55^{\mathrm{e}}$ & $0.00^{\mathrm{f}}$ \\
\hline Stem & $18.43^{\mathrm{b}}$ & $18.70^{\mathrm{b}}$ & $17.75^{\mathrm{bc}}$ & $16.11^{\mathrm{bc}}$ & $16.85^{\mathrm{bc}}$ & $20.05^{\mathrm{bc}}$ & $32.65^{\mathrm{a}}$ & $29.35^{\mathrm{a}}$ & $28.95^{\mathrm{a}}$ & $20.55^{\mathrm{bc}}$ \\
\hline Root & $25.90^{\mathrm{a}}$ & $24.35^{\mathrm{a}}$ & $23.03^{\mathrm{a}}$ & $18.30^{\mathrm{b}}$ & $14.98^{\mathrm{bc}}$ & $20.05^{\mathrm{bc}}$ & $29.55^{\mathrm{a}}$ & $29.95^{\mathrm{a}}$ & $27.25^{\mathrm{a}}$ & $13.08^{\mathrm{d}}$ \\
\hline LSD & & & 4.239 & & & & & 5.424 & & \\
\hline \multicolumn{11}{|c|}{ Common bean } \\
\hline Leaf & $18.18^{\mathrm{ab}}$ & $20.23^{\mathrm{a}}$ & $19.30^{\mathrm{ab}}$ & $12.80^{\text {cde }}$ & $6.05^{\mathrm{f}}$ & $25.38^{\mathrm{abcd}}$ & $23.10^{\text {bcde }}$ & $20.55^{\text {def }}$ & $15.75^{\mathrm{fg}}$ & $6.80^{\mathrm{i}}$ \\
\hline Stem & $1858^{\mathrm{ab}}$ & $9.65^{\mathrm{ef}}$ & $14.50^{\text {bcde }}$ & $12.05^{\mathrm{de}}$ & $0.00^{\mathrm{g}}$ & $26.55^{\mathrm{abc}}$ & $26.90^{\mathrm{ab}}$ & $21.75^{\text {cde }}$ & $12.25^{\mathrm{gh}}$ & $8.75^{\mathrm{hi}}$ \\
\hline Root & $19.44^{\mathrm{ab}}$ & $17.95^{\mathrm{abc}}$ & $16.53^{\mathrm{abcd}}$ & $9.90^{\mathrm{ef}}$ & $5.18^{\mathrm{fg}}$ & $25.15^{\mathrm{abcd}}$ & $28.40^{\mathrm{a}}$ & $19.65^{\mathrm{ef}}$ & $20.40^{\mathrm{def}}$ & $18.25^{\mathrm{ef}}$ \\
\hline LSD & & & 5.242 & & & & & 5.039 & & \\
\hline \multicolumn{11}{|c|}{ Radish } \\
\hline Leaf & $17.48^{\mathrm{abc}}$ & $19.70^{\mathrm{a}}$ & $14.73^{\mathrm{bc}}$ & $5.38^{\mathrm{e}}$ & $0.25^{\mathrm{f}}$ & $20.90^{\text {bcd }}$ & $20.25^{\mathrm{cd}}$ & $12.45^{\mathrm{e}}$ & $5.55^{\mathrm{f}}$ & $0.00^{\mathrm{f}}$ \\
\hline Stem & $15.74^{\mathrm{abc}}$ & $17.73^{\mathrm{abc}}$ & $17.80^{\mathrm{abc}}$ & $18.53^{\mathrm{ab}}$ & $10.01^{\mathrm{d}}$ & $17.55^{\text {cde }}$ & $32.35^{\mathrm{a}}$ & $32.65^{\mathrm{a}}$ & $32.05^{\mathrm{a}}$ & $23.25^{\mathrm{bc}}$ \\
\hline Root & $17.25^{\mathrm{abc}}$ & $17.45^{\mathrm{abc}}$ & $14.25^{\mathrm{c}}$ & $14.45^{\mathrm{c}}$ & $2.19^{\mathrm{ef}}$ & $20.75^{\mathrm{bcd}}$ & $30.05^{\mathrm{a}}$ & $26.55^{\mathrm{ab}}$ & $22.60^{\mathrm{bc}}$ & $15.95^{\mathrm{de}}$ \\
\hline LSD & & & 3.977 & & & & & 6.245 & & \\
\hline \multicolumn{11}{|c|}{ Showy rattlebox } \\
\hline Leaf & $17.59^{\mathrm{ab}}$ & $18.05^{\mathrm{ab}}$ & $15.21^{\mathrm{bc}}$ & $10.75^{\mathrm{c}}$ & $3.56^{\mathrm{d}}$ & $29.00^{\text {cde }}$ & $29.55^{\text {bcde }}$ & $11.80^{\mathrm{f}}$ & $5.10^{\mathrm{gh}}$ & $0.20^{\mathrm{h}}$ \\
\hline Stem & $17.53^{\mathrm{ab}}$ & $18.50^{\mathrm{ab}}$ & $20.30^{\mathrm{a}}$ & $17.25^{\mathrm{ab}}$ & $11.18^{\mathrm{c}}$ & $31.45^{\mathrm{bcd}}$ & $34.20^{\mathrm{abc}}$ & $28.90^{\text {de }}$ & $24.90^{\mathrm{e}}$ & $8.75^{\mathrm{fg}}$ \\
\hline Root & $18.03^{\mathrm{ab}}$ & $18.32^{\mathrm{ab}}$ & $19.25^{\mathrm{ab}}$ & $19.25^{\mathrm{ab}}$ & $18.08^{\mathrm{ab}}$ & $28.75^{\mathrm{de}}$ & $36.75^{\mathrm{a}}$ & $34.75^{\mathrm{ab}}$ & $28.65^{\mathrm{de}}$ & $27.00^{\text {de }}$ \\
\hline LSD & & & 4.569 & & & & & 5.237 & & \\
\hline \multicolumn{11}{|c|}{ Tephrosia } \\
\hline Leaf & $1.67^{\mathrm{c}}$ & $1.84^{\mathrm{abc}}$ & $1.80^{\mathrm{abc}}$ & $1.82^{\mathrm{abc}}$ & $1.62^{\mathrm{ab}}$ & $22.10^{\text {cde }}$ & $17.85^{\mathrm{ef}}$ & $15.35^{\mathrm{f}}$ & $8.05^{\mathrm{g}}$ & $2.85^{\mathrm{h}}$ \\
\hline Stem & $1.92^{\mathrm{ab}}$ & $0.91^{\mathrm{d}}$ & $0.24^{\mathrm{e}}$ & $0.00^{\mathrm{f}}$ & $0.00^{\mathrm{f}}$ & $22.30^{\text {bcde }}$ & $24.15^{\mathrm{bcd}}$ & $21.25^{\mathrm{de}}$ & $14.35^{\mathrm{f}}$ & $13.25^{\mathrm{f}}$ \\
\hline Root & $1.75^{\mathrm{bc}}$ & $1.92^{\mathrm{ab}}$ & $1.88^{\mathrm{abc}}$ & $1.99^{\mathrm{a}}$ & $1.98^{\mathrm{ab}}$ & $22.85^{\text {bcde }}$ & $30.05^{\mathrm{a}}$ & $27.35^{\mathrm{ab}}$ & $26.60^{\mathrm{abc}}$ & $24.75^{\mathrm{bcd}}$ \\
\hline LSD & & & 0.234 & & & & & 5.089 & & \\
\hline \multicolumn{11}{|c|}{ Black sunnhemp } \\
\hline Leaf & $1.57^{\mathrm{abcd}}$ & $1.49^{\mathrm{bcd}}$ & $1.44^{\mathrm{cd}}$ & $1.37^{\mathrm{d}}$ & $0.28^{\mathrm{c}}$ & $30.20^{\mathrm{bc}}$ & $25.20^{\mathrm{cd}}$ & $8.95^{\mathrm{e}}$ & $2.70^{\mathrm{f}}$ & $0.00^{\mathrm{f}}$ \\
\hline Stem & $1.66^{\mathrm{abcd}}$ & $1.70^{\mathrm{abcd}}$ & $1.75^{\mathrm{abcd}}$ & $1.48^{\mathrm{bcd}}$ & $1.83^{\mathrm{abcd}}$ & $29.75^{\mathrm{bcd}}$ & $37.45^{\mathrm{a}}$ & $29.50^{\mathrm{bcd}}$ & $23.95^{\mathrm{d}}$ & $14.30^{\mathrm{e}}$ \\
\hline Root & $1.54^{\mathrm{abcd}}$ & $1.90^{\mathrm{abc}}$ & $2.00^{\mathrm{a}}$ & $1.93^{\mathrm{ab}}$ & $1.87^{\mathrm{abc}}$ & $30.40^{\mathrm{bc}}$ & $35.35^{\mathrm{ab}}$ & $31.30^{\mathrm{b}}$ & $30.25^{\mathrm{bc}}$ & $24.45^{\mathrm{cd}}$ \\
\hline LSD & & & 0.472 & & & & & 6.283 & & \\
\hline
\end{tabular}

Means followed by the same letter for each GMCC are not significantly different at $p<0.05$.

and plumule and radicle growth inhibition of weed seeds treated with whole plant aqueous extracts of these cover crops. In this study, the different tissue aqueous extracts showed variable inhibitory activity suggesting differences in concentrations of potent allelochemicals in the different plant parts or different active compounds. Leaf extracts exhibited higher germination inhibition, suggesting the presence of more potent allelochemicals in the foliage of cover crops than the other tissues. Gulzar and Sidiquie [36] working with different plant parts of Eclipta alba (L.) Hassk reported that foliar extracts were generally more potent than stem and root extracts probably due to the greater metabolic activity in the foliage.
Results showed that only radish roots exhibited phytotoxic activity on goosegrass, whereas its leaf residues were more phytotoxic to germination and seedling growth of blackjack. Consistent with the current results, Ali [37] reported the inhibition of germination of other annual grasses including wheat (Triticum aestivum L.), barley (Hordeum vulgare L.), canary grass (Phalaris canariensis L.), and black mustard (Brassica nigra L.) using aqueous root extracts of radish. The presence of protein synthesis inhibitors, namely, vanilic acid and ferulic acid in the roots of radish has previously been reported [38]. The lack of the phytotoxic activity of radish root extracts on black Jack demonstrated in this study contradicts the findings of Zhou and $\mathrm{Yu}$ [39] who reported the inhibitory 
TABLE 6: Effect of aqueous extracts of eight green manure cover crops on the seedling vigor index (SV1) of goose grass and blackjack.

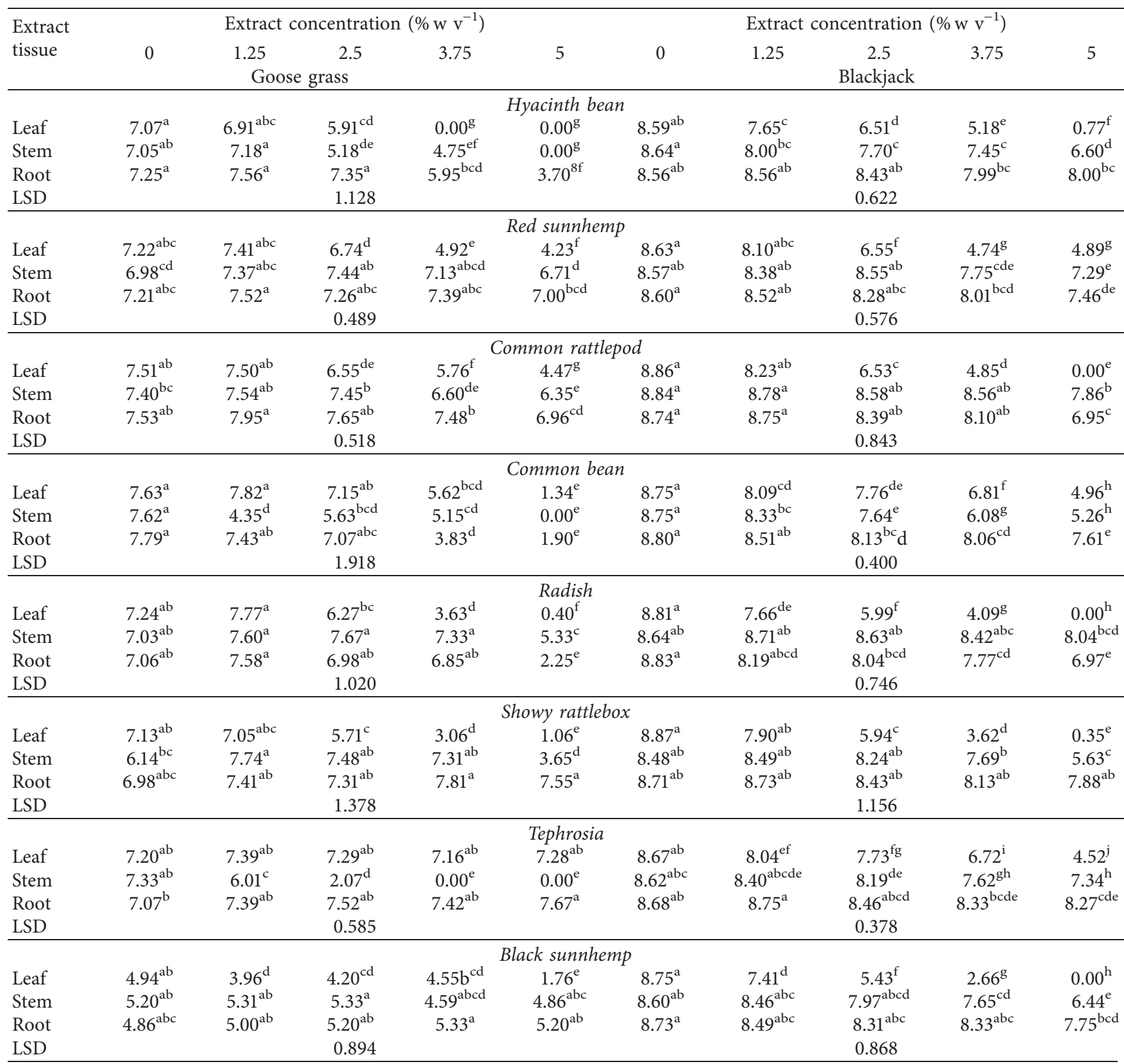

Means followed by the same letter for each GMCC are not significantly different at $p<0.05$.

activity of radish root extracts on other broadleaved annual plants. The inhibitory activity of radish leaf extracts could be attributed to the presence of isothiocynates that are released by the foliage of this crop [40]. Uludag et al. [41] reported the infestation of Johnsongrass [Sorghum halepense (L.) Pers] in cotton (Gossypium hirsutum L.) grown after the harvest of garden radish demonstrating the selective activity of allelochemicals produced by radish. Therefore, the insensitivity of blackjack seeds to root extracts of radish underscores that the broad spectrum weed control may best be achieved using whole plants as mulch or sources of extracts.

Aqueous extracts of all the Crotalaria species used in this study exhibited phytotoxic activity on the germination of goosegrass and blackjack in the order leaf $>$ stem $>$ root, indicating the presence of more potent allelochemicals in the leaves than any other plant part. These results concur with those of Adler and Chase [42] who reported the germination inhibition of smooth amaranth (Amaranthus hybridus L.), bell pepper (Capsicum annuum L.), and tomato (Solanum esculentum L.) where extracts and mulches of black sunnhemp were used. Black sunnhemp roots, leaves, stems, and seeds are known to contain several dehydropyrrolidizine alkaloids such as junceine, trichodesmine, isohemijunceines A, B, C, and acetyl isohenmijunceines [8]. Pilbeam and Bell [43] identified the nonprotein 5-hydroxy-2-aminohexanoic acid as the allelochemical responsible for the phytotoxic activity exhibited by black sunnhemp. There are no reports of any phytotoxic allelochemicals isolated from common 
TABLE 7: Effect of soil incorporated residues of different plant parts of cover crops on emergence (\%), dry weight, and seedling vigor index (SVII) of blackjack.

\begin{tabular}{|c|c|c|c|c|c|c|c|c|}
\hline Cover crop & Leaf & $\%$ inhibition & Stem & $\%$ inhibition & Root & $\%$ inhibition & Mean \% inhibition & Rank \\
\hline \multicolumn{9}{|c|}{ Emergence (\%) } \\
\hline Control & $67.0^{\mathrm{a}}$ & & $67.0^{\mathrm{a}}$ & & $67.0^{\mathrm{a}}$ & & & \\
\hline Hyacinth bean & $8.0^{\mathrm{c}}$ & 88 & $14.0^{\mathrm{dc}}$ & 79 & $12.0^{\mathrm{de}}$ & 82 & 83 & $2^{* * *}$ \\
\hline Red sunnhemp & $8.0^{\mathrm{c}}$ & 88 & $29.0^{\mathrm{bc}}$ & 57 & $19.0^{\text {cde }}$ & 72 & 72 & $4^{* *}$ \\
\hline Showy rattlebox & $39.0^{\mathrm{b}}$ & 42 & $24.0^{\mathrm{bc}}$ & 64 & $5.0^{\mathrm{e}}$ & 93 & 66 & $8^{* *}$ \\
\hline Common bean & $4.0^{\mathrm{c}}$ & 94 & $29.0^{\mathrm{bc}}$ & 57 & $31.0^{\mathrm{bc}}$ & 54 & 68 & $7^{* *}$ \\
\hline $\begin{array}{l}\text { Common } \\
\text { rattlepod }\end{array}$ & $34.0^{\mathrm{b}}$ & 49 & $34.0^{\mathrm{b}}$ & 49 & $35.0^{\mathrm{b}}$ & 48 & 49 & $10^{*}$ \\
\hline Radish & $6.0^{c}$ & 91 & $28.0^{\mathrm{bc}}$ & 58 & $27.0^{\mathrm{bcd}}$ & 60 & 70 & $5^{* *}$ \\
\hline Tephrosia & $11.0^{\mathrm{c}}$ & 84 & $4.0^{\mathrm{d}}$ & 94 & $10.0^{\mathrm{e}}$ & 85 & 88 & $1^{* * *}$ \\
\hline Black sunnhemp & $9.0^{\mathrm{c}}$ & 87 & $29.0^{\mathrm{bc}}$ & 57 & $36.0^{\mathrm{b}}$ & 46 & 63 & $9^{* *}$ \\
\hline \multicolumn{9}{|c|}{ Dry weight $(g)$} \\
\hline Control & $0.074^{\mathrm{a}}$ & & $0.074^{\mathrm{a}}$ & & $0.074^{\mathrm{a}}$ & & & \\
\hline Hyacinth bean & $0.009^{c}$ & 88 & $0.01^{\mathrm{dc}}$ & 86 & $0.008^{\mathrm{c}}$ & 89 & 88 & $1^{* * *}$ \\
\hline Red sunnhemp & $0.020^{\mathrm{bc}}$ & 73 & $0.046^{\mathrm{b}}$ & 38 & $0.018^{\mathrm{bc}}$ & 76 & 62 & $8^{* *}$ \\
\hline Showy rattlebox & $0.047^{\mathrm{b}}$ & 36 & $0.029^{c}$ & 61 & $0.044^{\mathrm{b}}$ & 41 & 46 & $10^{* *}$ \\
\hline Common bean & $0.014^{\mathrm{c}}$ & 81 & $0.028^{\mathrm{c}}$ & 62 & $0.037^{\mathrm{bc}}$ & 50 & 64 & $6^{* *}$ \\
\hline $\begin{array}{l}\text { Common } \\
\text { rattlepod }\end{array}$ & $0.018^{\mathrm{c}}$ & 76 & $0.030^{\mathrm{c}}$ & 59 & $0.028^{b c}$ & 62 & 66 & $7^{* *}$ \\
\hline Radish & $0.021^{\mathrm{bc}}$ & 72 & $0.041^{\mathrm{b}}$ & 45 & $0.035^{\mathrm{bc}}$ & 53 & 56 & $9^{* *}$ \\
\hline Tephrosia & $0.017^{\mathrm{c}}$ & 77 & $0.001^{\mathrm{d}}$ & 99 & $0.022^{\mathrm{bc}}$ & 70 & 82 & $2^{* * *}$ \\
\hline Black sunnhemp & $0.023^{\mathrm{bc}}$ & 69 & $0.023^{\mathrm{dc}}$ & 69 & $0.023^{b c}$ & 69 & 69 & $4^{* *}$ \\
\hline \multicolumn{9}{|c|}{ Seedling vigor index (SVII) } \\
\hline Control & $2.30^{\mathrm{c}}(5.007)$ & & $2.30^{\mathrm{c}}(5.007)$ & & $2.30^{\mathrm{c}}(5.007)$ & & & \\
\hline Hyacinth bean & $0.77^{\mathrm{a}}(0.087)$ & 98 & $0.83^{\mathrm{ab}}(0.190)$ & 96 & $0.79^{\mathrm{a}}(0.132)$ & 97 & 97 & $1^{* * *}$ \\
\hline Red sunnhemp & $0.83^{\mathrm{a}}(0.200)$ & 96 & $1.36^{\mathrm{c}}(0.401)$ & 92 & $0.92^{\text {abcd }}(0.359)$ & 93 & 94 & $7^{* * *}$ \\
\hline Showy rattlebox & $1.50^{\mathrm{b}}(0.914)$ & 82 & $1.15^{\mathrm{abc}}(0.031)$ & 99 & $0.83^{\mathrm{ab}}(0.197)$ & 96 & 92 & $10^{* *}$ \\
\hline Common bean & $0.76^{\mathrm{a}}(0.082)$ & 98 & $1.15^{\mathrm{abc}}(0.873)$ & 83 & $1.29^{\mathrm{de}}(1.207)$ & 76 & 86 & $6^{* * *}$ \\
\hline $\begin{array}{l}\text { Common } \\
\text { rattlepod }\end{array}$ & $0.99^{\mathrm{a}}(0.560)$ & 89 & $1.19^{\mathrm{bc}}(0.980)$ & 80 & $1.12^{\text {abcde }}(0.820)$ & 84 & 84 & $8^{* * *}$ \\
\hline Radish & $0.82^{\mathrm{a}}(0.192)$ & 96 & $1.27^{\mathrm{bc}}(1.224)$ & 76 & $1.21^{\text {cde }}(1.016)$ & 80 & 84 & $9^{* * *}$ \\
\hline Tephrosia & $0.85^{\mathrm{a}}(0.225)$ & 96 & $0.72^{\mathrm{a}}(0.016)$ & 100 & $0.85^{\mathrm{abc}}(0.242)$ & 95 & 97 & $2^{* * *}$ \\
\hline Black sunnhemp & $0.87^{\mathrm{a}}(0.280)$ & 94 & $1.07^{\mathrm{abc}}(0.660)$ & 87 & $1.16^{\text {bcde }}(0.960)$ & 81 & 87 & $4^{* * *}$ \\
\hline
\end{tabular}

Means followed by the same letter in the same column are not significantly different at $p<0.05 .{ }^{* * *},{ }^{* *},{ }^{*}$ represent species with mean inhibition over control $\geq 80 \%, \geq 50 \%$, and $\geq 20 \%$, respectively. Data were $\sqrt{ }(x+0.5)$ transformed. Untransformed data given in brackets were used to calculate the inhibition percentages.

rattlepod, showy rattlebox, red sunnhemp, and hyacinth bean. However, results obtained in this study indicate the potential of these moderately used cover crops as sources of bio-herbicidal compounds for annual grass and broad leaf control. The fact that the aqueous extracts of the above ground parts of these cover crops were phytotoxic to weeds makes them promising candidates for use as allelopathic cover crops due to the ability of the plants to produce a lot of foliage within a short period of time.

Tephrosia leaves were highly inhibitory to the germination and seedling growth of both weeds. The allelopathic activity of tephrosia leaf extracts and volatiles, as well as soil incorporated biomass, on several weeds was reported previously [44]. These findings corroborate the work of Purohit and Pandya [31] who reported reduced weed germination of Indian Nettle (Acalypha indica L.), spiny amaranth (Amaranthus spinosus L.), swollen fingergrass (Chloris barbata Sw.), and marvel grass (Dichanthium annulatum Forssk.) seeds that had been treated with tephrosia extracts. They attributed the inhibitory activity of tephrosia leaves to the presence of coumarins, flavonoids, carotenoids, and quercetin [31].
Furthermore, results obtained in this study proved the hypothesis that soil incorporated biomass of cover crops could suppress the emergence and growth of weeds. The biomass of all the cover crop plant tissues used differentially suppressed the emergence of both weeds. It is suggested that the suppression of emergence and seedling growth observed was due to the presence of allelochemicals that were released by the cover crop residues into the soil. These findings confirm the allelopathic suppression of the weeds that was observed in the laboratory bioassays in this study. The suppression of weed emergence by soil-incorporated biomass of allelopathic plants was also reported by several other authors $[3,13,42]$. The inhibition of weed emergence could be due to the disruption of mitosis, which results in a reduction in root elongation and a concomitant reduction in root volume [45]. As a result, the roots fail to absorb enough moisture to support the emergence of the germinated seedling. For example, Soares et al. [46] reported that L-DOPA, an allelochemical, found in velvet bean and many species of the Fabaceae family caused deformed and malfunctioning roots. This interference with root growth could 
TABLE 8: Effect of soil-incorporated biomass of different plant parts of cover crops on the emergence of goose grass.

\begin{tabular}{|c|c|c|c|c|c|c|c|c|}
\hline Cover crop & Leaf & $\%$ inhibition & Stem & $\%$ inhibition & Root & $\%$ inhibition & $\begin{array}{l}\text { Mean \% } \\
\text { inhibition }\end{array}$ & Rank \\
\hline \multicolumn{9}{|c|}{ Emergence (\%) } \\
\hline Control & $98.3^{\mathrm{e}}$ & & $98.3^{\mathrm{e}^{-10}}$ & & $98.3^{\mathrm{e}}$ & & & \\
\hline Hyacinth bean & $44.4^{\mathrm{a}}$ & 55 & $38.1^{\mathrm{ab}}$ & 61 & $32.5^{\mathrm{ab}}$ & 67 & 61 & $1^{* *}$ \\
\hline Red sunnhemp & $45.7^{\mathrm{a}}$ & 54 & $56.9^{\mathrm{cd}}$ & 42 & $42.5^{\mathrm{bc}}$ & 57 & 51 & $6^{* *}$ \\
\hline Showy rattlebox & $88.0^{\mathrm{de}}$ & 10 & $89.0^{\mathrm{e}}$ & 9 & $86.0^{\mathrm{e}}$ & 13 & 11 & 10 \\
\hline Common bean & $75.0^{\mathrm{cd}}$ & 24 & $68.5^{\mathrm{d}}$ & 30 & $63.5^{\mathrm{d}}$ & 35 & 30 & $9^{*}$ \\
\hline $\begin{array}{l}\text { Common } \\
\text { rattlepod }\end{array}$ & $43.5^{\mathrm{a}}$ & 56 & $43.5^{\mathrm{abc}}$ & 56 & $31.5^{\mathrm{ab}}$ & 68 & 60 & $3^{* *}$ \\
\hline Radish & $48.0^{\mathrm{a}}$ & 51 & $42.0^{\mathrm{abc}}$ & 57 & $26.0^{\mathrm{a}}$ & 74 & 61 & $1^{* *}$ \\
\hline Tephrosia & $57.5^{\mathrm{ab}}$ & 42 & $35.5^{\mathrm{ab}}$ & 64 & $44.5^{\mathrm{bc}}$ & 55 & 53 & $5^{* *}$ \\
\hline Black sunnhemp & $71.0^{\mathrm{bc}}$ & 28 & $29.0^{\mathrm{a}}$ & 70 & $44.5^{\mathrm{bc}}$ & 55 & 51 & $6^{* *}$ \\
\hline \multicolumn{9}{|c|}{ Dry weight $(g)$} \\
\hline Control & $1.14^{\mathrm{ef}}$ & & $1.14^{\mathrm{b}}$ & & $1.14^{\mathrm{c}}$ & & & \\
\hline Hyacinth bean & $1.13^{\mathrm{ef}}$ & 1 & $0.09^{\mathrm{a}}$ & 92 & $0.06^{\mathrm{a}}$ & 95 & 63 & $8^{* *}$ \\
\hline Red sunnhemp & $0.24^{\mathrm{ab}}$ & 79 & $0.04^{\mathrm{a}}$ & 96 & $0.03^{\mathrm{a}}$ & 97 & 91 & $3^{* * *}$ \\
\hline Showy rattlebox & $0.87^{\mathrm{de}}$ & 24 & $1.28^{\mathrm{b}}$ & -12 & $0.32^{\mathrm{b}}$ & 72 & 28 & 10 \\
\hline Common bean & $0.42^{\mathrm{abc}}$ & 63 & $0.05^{\mathrm{a}}$ & 96 & $0.03^{\mathrm{a}}$ & 97 & 85 & $4^{* * *}$ \\
\hline $\begin{array}{l}\text { Common } \\
\text { rattlepod }\end{array}$ & $0.25^{\mathrm{a}}$ & 78 & $0.02^{\mathrm{a}}$ & 98 & $0.02^{\mathrm{a}}$ & 98 & 92 & $2^{* * *}$ \\
\hline Radish & $0.72^{\mathrm{cd}}$ & 37 & $0.05^{\mathrm{a}}$ & 96 & $0.04^{\mathrm{a}}$ & 96 & 76 & $6^{* *}$ \\
\hline Tephrosia & $0.81^{\mathrm{de}}$ & 29 & $0.02^{\mathrm{a}}$ & 98 & $0.04^{\mathrm{a}}$ & 96 & 75 & $7^{* *}$ \\
\hline Black sunnhemp & $0.58^{\mathrm{bcd}}$ & 49 & $0.01^{\mathrm{a}}$ & 99 & $0.03^{\mathrm{a}}$ & 97 & 82 & $5^{* *}$ \\
\hline \multicolumn{9}{|c|}{ Seedling vigor index (SVII) } \\
\hline Control & $\begin{array}{c}9.75^{\mathrm{de}} \\
(111.78)\end{array}$ & & $9.75^{\text {de }}(111.78)$ & & $\begin{array}{c}9.75^{\mathrm{de}} \\
(111.78)\end{array}$ & & & \\
\hline Hyacinth bean & $6.86^{\mathrm{bc}}(49.91)$ & 55 & $1.86^{\mathrm{ab}}(3.74)$ & 97 & $1.34^{\mathrm{a}}(1.63)$ & 99 & 84 & $8^{* * *}$ \\
\hline Red sunnhemp & $3.06^{\mathrm{a}}(10.66)$ & 90 & $1.63^{\mathrm{ab}}(2.46)$ & 98 & $1.37^{\mathrm{a}}(1.51)$ & 99 & 96 & $3^{* * *}$ \\
\hline Showy rattlebox & $8.62^{\mathrm{cd}}(76.62)$ & 31 & $\begin{array}{c}10.64^{\mathrm{cd}} \\
(114.16)\end{array}$ & -2 & $4.96^{\mathrm{b}}(25.83)$ & 77 & 35 & 10 \\
\hline Common bean & $5.59^{\mathrm{b}}(35)$ & 68 & $1.84^{\mathrm{ab}}(3.29)$ & 97 & $1.42^{\mathrm{a}}(1.68)$ & 98 & 88 & $4^{* * *}$ \\
\hline $\begin{array}{l}\text { Common } \\
\text { rattlepod }\end{array}$ & $3.30^{\mathrm{a}}(11.02)$ & 90 & $1.22^{\mathrm{a}}(11.48)$ & 99 & $1.00^{\mathrm{a}}(0.56)$ & 99 & 96 & $2^{* * *}$ \\
\hline Radish & $5.78^{\mathrm{b}}(36.38)$ & 67 & $1.55^{\mathrm{ab}}(2.18)$ & 98 & $1.18^{\mathrm{a}}(0.95)$ & 99 & 88 & $6^{* * *}$ \\
\hline Tephrosia & $6.81^{b c}(48.22)$ & 57 & $1.11^{\mathrm{a}}(0.77)$ & 99 & $1.41^{\mathrm{a}}(21.63)$ & 99 & 85 & $7^{* * *}$ \\
\hline Black sunnhemp & $6.38^{\mathrm{b}}(42.20)$ & 62 & $1.55^{\mathrm{a}}(0.53)$ & 100 & $1.44^{\mathrm{a}}(21.76)$ & 98 & 87 & $5^{* * *}$ \\
\hline
\end{tabular}

Means followed by the same letter in the same column are not significantly different at $p<0.05 .{ }^{* * *},{ }^{* *}$, and ${ }^{*}$ represent species with mean inhibition over control $\geq 80 \%, \geq 50 \%$, and $\geq 20 \%$, respectively. Data were $\sqrt{ }(x+0.5)$ transformed. Untransformed data given in brackets were used to calculate the inhibition percentages.

be responsible for reduced emergence and seedling dry weight that was observed in this study due to the poor growth of the nutrient and moisture starved plants [47].

The study revealed that the ability of the soil-incorporated biomass of different plant parts varied significantly among cover crops with leaves showing more inhibitory activity than the stems and roots on blackjack, but all the tissues exhibited the same level of germination and growth suppression on goose grass. The presence of more putative allelochemicals in leaf tissues of other plants compared to stems and roots has previously been reported [36] and has been attributed to greater metabolic activity in the foliage than other plant parts, except in radish where roots are the principal storage organ of the plant $[13,41]$. The other cover crops showed variable efficacy in inhibiting weed emergence. Variable inhibition was observed on goose grass with leaf and stem biomass of showy rattlebox exhibiting lack of inhibitory activity on this monocotyledonous weed.
Morphological examination showed that the goose grass plants that had emerged turned yellow and slowly became necrotic, a symptom, which is characteristic of photosystem 2 inhibiting herbicides. The fact that chlorosis was only observed in pots where soil was mixed with GMCC biomass but not in the control where the soil was not mixed with GMCC biomass suggests the presence of photosynthesis inhibiting allelochemicals. Alternatively, chlorosis could be a result of the reduced nutrient uptake, which can be caused by a reduction in root volume and function triggered by the phytotoxic activity of allelochemicals on root cells [48]. There is also a possibility that the allelochemicals produced could interact with the soil by increasing cation exchange capacity (CEC), which led to the reduction of nutrient uptake. It is also possible that the allelochemicals could have reacted with nutrients to form insoluble complexes that are not available for plant uptake resulting in chlorosis. 
The different cover crop tissues differentially affected the dry weight accumulation and vigor indices of goose grass. The fact that some of the cover crop treatments reduced emergence, but the stimulated dry weight of weeds shows that phytotoxicity lasted for only a short time [25]. Alternatively, the high biomass in pots that had low emergence could be a result of reduced intraspecific competition for resources amongst the plants in the same pot. This could probably be the reason why the goosegrass dry weight in the control and velvet bean was similar to that of hyacinth bean although both had twice as many plants that emerged than the hyacinth bean. Whilst it is possible to ascribe the differences in emergence percentages to the presence of possible allelochemicals in the cover crop tissues, it is probable that many other factors could also be responsible for differences in dry matter accumulation observed. These findings are in agreement with those of Yang et al. [49] who reported that $0.002 \mathrm{~g}$ of Eucalyptus spp leaf extracts increased the biomass of broadleaved weeds in potted experiments. Growth stimulation was not observed in blackjack, which demonstrates that this dicotyledonous weed is more susceptible to allelochemicals than the monocotyledonous goose grass. These findings contradict those of Runzika et al. [35] who reported the suppression of the dry weight of these two weeds by whole plant extracts of the cover crops used in this study. The differences could be because they used whole plant extracts where allelochemicals from different plant parts could have acted synergistically. Moreover, they used higher residue concentrations of $10 \%$ compared to $1 \%$ used in this study. The growth stimulation observed can be attributed to high levels of nitrogen in the leaves of these leguminous cover crops [50] or hormetic effects of allelochemicals at low concentrations [3]. Although many studies have demonstrated the allelopathic potential of some cover crops, weed suppression was observed with artificially high concentrations yet allelochemicals exist in very low concentrations under field conditions [51]. As such, these present results are of practical significance since they represent conditions that are most likely to occur under natural conditions. In such cases where hormesis is most likely to occur, it may be necessary to combine the use of allelopathic mulches or extracts with herbicides or other weed control options in order to achieve a satisfactory control of weeds [45].

\section{Conclusion}

In conclusion, the study indicated that all the GMCCs used in this study contain possible allelochemicals that could be responsible for the inhibition exhibited on goose grass and blackjack germination, as well as seedling growth. Leaf extracts of all the GMCCs were more efficient in inhibiting germination and seedling growth of both weeds, except radish roots extracts that exhibited greater phytotoxic activity than the other tissue extracts. These results provide a reasonable basis for suggesting the use of these eight cover crop aqueous extracts and/or mulches for broad spectrum weed control in maize. Whilst these findings complement the results from previous research studies where these cover crops where used, there is still a knowledge gap on the possible mode of action of these chemicals in susceptible plants. Future studies should, therefore, focus on identifying and quantifying the putative allelochemicals in different plant parts of the cover crops, as well as evaluating their efficacy on weeds and crops when applied postemergence. It is further recommended that the allelopathic potential of these cover crops can be studied under field conditions to determine their efficacy in reducing seed viability and concomitantly weed emergence in arable fields. These GMCCs are also known to be resistant to common pests and diseases, as well as reduces weeds by their smothering effect since they produce a lot of biomass rapidly. Farmers are, therefore, likely to experience remarkable weed germination and growth suppression in the early season in addition to the other known benefits of these cover crops if these cover crop tissues are used at concentrations that are inhibitory to weed growth [52-54].

\section{Data Availability}

The data used to support the findings of this study are available from the corresponding author upon request.

\section{Conflicts of Interest}

The authors declare that they have no conflicts of interest.

\section{Acknowledgments}

This research was supported through a capacity building competitive grant training of the next generation of scientists provided by Carnegie Corporation of New York through the Regional Universities Forum for Capacity Building in Agriculture (RUFORUM).

\section{References}

[1] Y. Lou, A. S. Davis, and A. C. Yannarell, "Interactions between allelochemicals and the microbial community affect weed suppression following cover crop residue incorporation into soil," Plant and Soil, vol. 399, no. 1-2, pp. 357-371, 2016.

[2] O. A. Abdin, X. M. Zhou, D. Cloutier, D. C. Coulman, M. A. Faris, and D. L. Smith, "Cover crops and interrow tillage for weed control in short season maize (Zea mays)," European Journal of Agronomy, vol. 12, no. 2, pp. 93-102, 2000.

[3] V. Rueda-Ayala, O. Jaeck, and R. Gerhards, "Investigation of biochemical and competitive effects of cover crops on crops and weeds," Crop Protection, vol. 71, pp. 79-87, 2015.

[4] B. Mhlanga, S. Cheesman, B. Maasdorp, W. Mupangwa, and C. Thierfelder, "Contribution of cover crops to the productivity of maize-based conservation agriculture systems in Zimbabwe," Crop Science, vol. 55, no. 4, pp. 1791-1805, 2015.

[5] V. Nichols, N. Verhulst, R. Cox, and B. Govaerts, "Weed dynamics and conservation agriculture principles: a review," Field Crops Research, vol. 183, pp. 56-68, 2015.

[6] J. K. Norsworthy, M. McClelland, G. Griffith, S. K. Bangarwa, and J. Still, "Evaluation of cereal and brassicaceae cover crops in conservation-tillage, enhanced, glyphosate-resistant cotton," Weed Technology, vol. 25, no. 1, pp. 6-13, 2011.

[7] Z. R. Khan, C. A. O. Midega, T. J. A. Bruce, A. M. Hooper, and J. A. Pickett, "Exploiting phytochemicals for developing a 
'push-pull' crop protection strategy for cereal farmers in Africa," Journal of Experimental Botany, vol. 61, no. 15, pp. 4185-4196, 2010.

[8] J. B. Morris, C. Chase, D. Treadwell et al., "Effect of sunn hemp (Crotalaria juncea L.) cutting date and planting density on weed suppression in Georgia, USA," Journal of Environmental Science and Health, Part B, vol. 50, no. 8, pp. 614-621, 2015.

[9] J. R. Teasdale, "Cover crops, smother plants, and weed management," in Integrated Weed and Soil Management, J. L. Hatfield, D. D. Buhler, and Stewart, Eds., Ann Arbor Press, Chelsea, MI, USA, 1998.

[10] T. Muoni and B. Mhlanga, "Weed management in Zimbabwean smallholder conservation agriculture farming sector," Asian Journal of Agriculture and Rural Development, vol. 4, pp. 267-276, 2014.

[11] S. R. Bezuidenhout, C. F. Reinhardt, and M. I. Whitwell, "Cover crops of oats, stooling rye and three annual ryegrass cultivars influence maize and Cyperus esculentus growth," Weed Research, vol. 52, no. 2, pp. 153-160, 2012.

[12] C. Halde, R. H. Gulden, and M. H. Entz, "Selecting cover crop mulches for organic rotational No-till systems in Manitoba, Canada," Agronomy Journal, vol. 106, no. 4, pp. 1193-1204, 2014.

[13] E. M. Skinner, J. C. Díaz-Pérez, S. C. Phatak, H. H. Schomberg, and W. Vencill, "Allelopathic effects of sunnhemp (Crotalaria juncea L.) on germination of vegetables and weeds," HortScience, vol. 47, no. 1, pp. 138-142, 2012.

[14] M. I. Ferreira and C. F. Reinhardt, "Field assessment of crop residues for allelopathic effects on both crops and weeds," Agronomy Journal, vol. 102, no. 6, pp. 1593-1600, 2010.

[15] M. Farooq, K. Jabran, Z. A. Cheema, A. Wahid, and K. H. Siddique, "The role of allelopathy in agricultural pest management," Pest Management Science, vol. 67, no. 5, pp. 493-506, 2011.

[16] T. d. G. Baratelli, A. C. Candido Gomes, L. A. Wessjohann, R. M. Kuster, and N. K. Simas, "Phytochemical and allelopathic studies of Terminalia catappa L. (Combretaceae)," Biochemical Systematics and Ecology, vol. 41, pp. 119-125, 2012.

[17] E. L. Rice, Allelopathy, Academic Press, Orlando, FL, USA, 2nd edition, 1984.

[18] M. J. Ayeni, "Bio-herbicidal potential of the aqueous extracts of the leaves and barks of Gliricidia sepium (Jacq) Kunth Ex Walp on the germination and seedling growth of Bidens pilosa L," Donnish Journals of Agricultural Research, vol. 3, pp. 1721, 2016.

[19] P. Barberi and B. Lo Cascio, "Long-term tillage and crop rotation effects on weed seedbank size and composition," Weed Research, vol. 41, no. 4, pp. 325-340, 2001.

[20] M. Liebman and A. Davis, "Integration of soil, crop and weed management in low-external-input farming systems," Weed Research, vol. 40, no. 1, pp. 27-48, 2000.

[21] J. T. Rugare, P. J. Pieterse, and S. Mabasa, "Evaluation of the potential of jack bean [Canavalia ensiformis (L.) DC.] and velvet bean [Mucuna pruriens (L.) DC.] aqueous extracts as post-emergence bio-herbicides for weed control in maize (Zea mays L.)," Asian Journal of Agriculture and Rural Development, vol. 10, no. 1, pp. 420-439, 2020a.

[22] J. T. Rugare, P. J. Pieterse, and S. Mabasa, "Effects of green manure cover crops (Canavalia ensiformis L. and Mucuna pruriens L.) on seed germination and seedling growth of maize and Eleusine indica L. and Bidens pilosa L. weeds," Allelopathy Journal, vol. 50, no. 1, pp. 121-139, 2020 b.
[23] USDA-NRCS, Carbon to Nitrogen Ratios in Cropping Systems. Soils, https://usda.gov/sqi, 2011.

[24] N. H. Hong, T. D. Xuan, T. Eiji, T. Hiroyuki, M. Mitsuhiro, and T. D. Khanh, "Screening for allelopathic potential of higher plants from Southeast Asia," Crop Protection, vol. 22, no. 6, pp. 829-836, 2003.

[25] T. D. Xuan, E. Tsuzuki, H. Terao et al., "Alfalfa, rice byproducts and their incorporation for weed control in rice," Weed Biology and Management, vol. 3, no. 2, pp. 137-144, 2003.

[26] J. T. Rugare, P. J. Pieterse, and S. Mabasa, "Effect of short-term maize-cover crop rotations on weed emergence, biomass and species composition under conservation agriculture," South African Journal of Plant and Soil, pp. 1-9, 2019.

[27] S. Sisodia and S. Siddiqui, "Allelopathic effect by aqueous extracts of different parts of Croton bonplandianum Baill. on some crop and weed plants," Journal of Agricultural Extension and Rural Development, vol. 2, pp. 22-28, 2010.

[28] A. Abdul-Baki and J. D. Anderson, "Vigor determination in soybean seed by multiple criteria," Crop Science, vol. 13, pp. 630-633, 1973.

[29] J. A. Caamal-Maldonado, J. J. Jimenez-Osornio, H. TorresBarragan, and A. L. Anaya, "The use of allelopathic legume cover and mulch species for weed control in cropping systems," Agronomy Journal, vol. 93, pp. 27-36, 2001.

[30] Y. Fujii, "Allelopathy in the natural and agricultural ecosystems and isolation of potent allelochemicals from Velvet bean (Mucuna pruriens) and Hairy vetch (Vicia villosa)," Biological Sciences in Space, vol. 17, no. 1, pp. 6-13, 2003.

[31] S. Purohit and N. Pandya, "Allelopathic activity of Ocimum sanctum L. and Tephrosia purpurea (L.) Pers leaf extracts on few common legumes and weeds," International Journal of Research in Plant Science, vol. 3, pp. 5-9, 2013.

[32] W. C. Conway, L. M. Smith, and J. F. Bergan, "Potential allelopathic interference by the exotic Chinese tallow tree (Sapium sebiferum)," The American Midland Naturalist, vol. 148 , no. 1 , pp. 43-53, 2002.

[33] C. T. A. da Cruiz-Silva and E. B. Matiazo, "Allelopathy of Crotalaria juncea aqueous extracts on germination and initial development of maize," IDESIA, vol. 33, pp. 27-32, 2015.

[34] S. Anese, P. U. Grisi, L. d. J. Jatobá, V. d. C. Pereira, and S. C. J. Gualtieri, "Phytotoxic activity of differents plant parts of Drimys brasiliensis miers on germination and seedling development," Bioscience Journal, vol. 31, no. 3, pp. 923-933, 2015.

[35] M. Runzika, J. T. Rugare, and S. Mabasa, "Screening green manure cover crops for their allelopathic effects on some important weeds found in Zimbabwe," Asian Journal of Rural and Agriculture Development, vol. 3, pp. 554-565, 2013.

[36] A. Gulzar and M. B. Siddiqui, "Allelopathic effect of aqueous extracts of different part of Eclipta alba (L.) Hassk. on some crop and weed plants," Journal of Agricultural Extension and Rural Development, vol. 6, pp. 55-60, 2010.

[37] K. A. Ali, "Allelopathic potential of radish on germination and growth of some crop and weed plants," International Journal of Biosciences, vol. 9, pp. 394-403, 2016.

[38] P. Jing, L.-H. Song, S.-Q. Shen, S.-J. Zhao, J. Pang, and B.-J. Qian, "Characterization of phytochemicals and antioxidant activities of red radish brines during lactic acid fermentation," Molecules, vol. 19, no. 7, pp. 9675-9688, 2014.

[39] Y. H. Zhou and Q. J. Yu, Allelochemicals and Photosynthesis. Allelopathy: A Physiological Process with Ecological Implications, Springer, Dordrecht, Netherlands, 2006. 
[40] J. Petersen, R. Belz, F. Walker, and K. Hurle, "Weed suppression by release of isothiocyanates from Turnip-Rape mulch,” Agronomy Journal, vol. 93, no. 1, pp. 37-43, 2001.

[41] A. Uludag, I. Uremis, M. Arslan, and D. Gozcu, "Allelopathy studies in weed science in Turkey-a review," Journal of Plant Diseases and Protection, vol. 20, pp. 419-426, 2006.

[42] M. J. Adler and C. A. Chase, "Comparison of the allelopathic potential of leguminous summer cover crops: cowpea, sunn hemp, and velvetbean," HortScience, vol. 42, no. 2, pp. 289-293, 2007.

[43] D. J. Pilbeam and E. A. Bell, "A reappraisal of the free amino acids in seeds of Crotalaria juncea (Leguminosae)," Phytochemistry, vol. 18, no. 2, pp. 320-321, 1979.

[44] R. L. Wang, X. Y. Yang, Y. Y. Song et al., "Allelopathic potential of Tephrosia vogelii Hook. f.: laboratory and field evaluation," Allelopathy Journal, vol. 28, pp. 53-62, 2011.

[45] K. Jabran, Z. A. Cheema, M. Farooq, and M. Hussain, "Lower doses of pendimethalin mixed with allelopathic crop water extracts for weed management in canola (Brassica napus)," International Journal of Agricultural Biology, vol. 12, pp. 335-340, 2010.

[46] A. R. Soares, R. Marchiosi, R. dC. Siqueira-Soares, R. Barbosa de Lima, W. Dantas dos Santos, and O. Ferrarese-Filho, "The role of L-Dopa in plants," Plant Behavior and Signaling, vol. 9, pp. 1-7, 2014.

[47] M. Niakan and K. Saberi, "Effects of Eucalyptus allelopathy on growth characters and antioxidant enzymes activity in Phalaris weed," Asian Journal of Plant Sciences, vol. 8, no. 6, pp. 440-446, 2009.

[48] M. Shahid, B. Ahmed, R. A. Khatak, G. Hassan, and H. Khan, "Response of wheat and its weeds to different allelopathic plant water extracts," Pakistan Weed Science Journal, vol. 12, pp. 61-68, 2006.

[49] I. Yang, Y. Chen, Y. Huang, J. Wang, and M. Wen, "Mixed allelopathic effect of Eucalyptus leaf litter and understorey fern in South China," Journal of Tropical Forest Science, vol. 28, pp. 436-455, 2016.

[50] M. d. M. Gomes, D. J. Bertoncelli Jr, G. A. C. Alves et al., "Allelopathic potential of the aqueous extract of Raphanus sativus L. on the germination of beans and corn seeds," OALib, vol. 4, no. 5, pp. 1-10, 2017.

[51] R. G. Belz, K. Hurle, and S. O. Duke, "Dose response-a challenge for allelopathy?" Nonlinearity in Biology, Toxicology, and Medicine, vol. 3, pp. 173-211, 2005.

[52] O. A. Chivinge, "A weed survey of arable small lands of the small-scale farming sector,” Zambezia, vol. 15, pp. 167-179, 1988.

[53] M. Liebman and D. N. Sundberg, "Seed mass affects the susceptibility of weed and crop species to phytotoxins extracted from red clover shoots," Weed Science, vol. 54, no. 2, pp. 340-345, 2006.

[54] R. Naderi and E. Bijanzadeh, "Allelopathic potential of leaf, stem and root extracts of some Iranian rice (Oryza sativa L.) cultivars on barnyard grass (Echinochloa crusgalli) growth," Plant Knowledge Journal, vol. 1, pp. 37-40, 2012. 